\title{
TUMOR NECROSIS FACTOR ALPHA AND KERATIN 17 EXPRESSION IN ORAL SUBMUCOUS FIBROSIS IN RAT MODEL
}

\author{
Ghada A. Abd El Latif*
}

\begin{abstract}
Background and Objective: Oral submucous fibrosis is an inflammatory and a premalignant lesion as classified by "World Health Organization". Its pathogenesis is related to collagen metabolism. Bleomycin is an anti-carcinogenic drug, but it causes pulmonary fibrosis. This study was carried out to study the role of tumor necrosis factor alpha and keratin 17 in pathogenesis of oral submucous fibrosis.
\end{abstract}

Study Design: Fifty pathologically-free female rats were divided into one control group and four test groups. They were injected by phosphate-buffered saline and Bleomycin into the buccal mucosae daily for 2, 4, 6 and 8 weeks, respectively. The histopathological changes was evaluated by studying the changes within epithelium tissue and lamina propria by $(\mathrm{H} \& \mathrm{E})$ and the expression of both (tumor necrosis factor alpha and keratin 17) using immunohistochemistry and enzyme linked immunosorbent assay respectively.

Results: The buccal mucosae of the test groups in comparison with control showed hyperplastic and hyperatrophic epithelial changes that gradually decreased with the severity of oral submucous fibrosis, with epithelial atrophy and focal dysplastic changes, which increase with severity of oral submucous fibrosis gradually. The lamina propria showed gradual increase in inflammatory cells, collagen formation and closure of the blood vessels. Regarding tumor necrosis factor alpha the area percent of immunoexpression, showed the lowest expression in the control and test groups showed gradually increase after 2, 4, 6,8 weeks within epithelium, on the other hand, the area percent of immunoexpression of tumor necrosis factor alpha within lamina propria showed gradually increase after 2, 4, 6 weeks, then decreased after 8 weeks. Regarding Keratin-17, the lowest value was recorded in control group while it increased gradually from the second week to the $8^{\text {th }}$ weeks.

Conclusion: Both protein molecules tumor necrosis factor alpha and keratin 17 appear to be related in case of oral submucous fibrosis. As tumor necrosis factor alpha and keratin 17 are interdependent regulators, they could be used as diagnostic makers and a prognostic mirror of oral submucous fibrosis cases. Tumor necrosis factor alpha inhibitory drugs can be targeted in new therapeutic agents to improve the prognosis of oral submucous fibrosis.

KEY WORDS: Bleomycin, oral submucous fibrosis, tumor necrosis factor alpha, keratin 17.

* Department of Oral Pathology, Faculty of Dentistry, Suez Canal University, Ismalia , Egypt 


\section{INTRODUCTION}

Bleomycin is an anti-carcinogenic drug used for treating cancer, but it has a limited side effect of pulmonary fibrosis ${ }^{(1)}$. It was reported that bleomycin as an anti-carcinogenic antibiotic is dose - dependent pulmonary fibrosis agent and leading to release of alveolar inflammatory cells like macrophages, neutrophils and eosinophils from the alveolar tissue (2). It was used to induce oral submucous fibrosis (OSF) in rat as in vivo animal model, that mimics to the human OSF clinically and microscopically, within short time ${ }^{(3)}$.

OSF is an inflammatory and premalignant condition as classified by the $\mathrm{WHO}^{(4)}$ and its malignant transformation to squamous cell carcinoma (SCC) is very clear specially in South and South-East Asian countries ${ }^{(5)}$.

Histopathological classification developed by Passi et al., (2017) to explain the connective tissue changes. They reported four stages of OSF, the first is the stage of inflammation, where inflammatory cells are obvious (neutrophils and lymphocytes) within subepithelial connective tissue, congested blood vessels, active fibroblast and fine collagen fibers. The second is the stage of hyalinization that shows less inflammatory cells infiltrations (eosinophils and lymphocytes) within subepithelial connective tissue, dilated blood vessels, decreased fibroblast activity, juxta-epithelial collagen fibers hyalinization and granulation changes in muscle layer. Third is the stage of fibrosis where it shows dense collagen hyalinization extended to the superficial muscle layers, closure of blood vessels, decreased inflammatory cells' infiltration as plasma cells and lymphocytes within subepithelial connective tissue and atrophy of muscle layer. Fourth is the stages of malignant transformation from erythroplakia changes to (SCC) ${ }^{(6)}$.

A previous study by Ray et al., (2016) explained the epithelial changes as it was observed that in addition to the classical atrophic epithelium which usually used to explain the epithelial changes in OSF, epithelial hyperplasia and dysplasia are clearly seen and they studied it by the evaluation of micronuclei, keratin protein and silver stainable nucleolar organizer regions AgNOR) expression, that could be an early diagnostic markers in OSF malignant transformation to oral squamous cell carcinoma $(\mathrm{OSCC})^{(7)}$.

Some researches had studied the increase of pathological collagen synthesis rather than physiological collagen degradation in OSF as it is highly related to the pathogenesis of $\operatorname{OSF}^{(8),(9)}$.

It was observed that many genes are related to the pathogenesis of OSF in different ways, where polymorphism of tumor necrosis factor alpha (TNF $\alpha$ ) is one of them ${ }^{(9)}$. Increase in TGF- $\alpha$ expression was reported in OSF, oral leukoplakia and oral SCC in relation to its expression in normal oral mucosa ${ }^{(10)}$. Also it was known that TNF $\alpha$ is secreted by alveolar macrophages during pulmonary fibrosis as an inflammatory response ${ }^{(2)}$.

$\mathrm{TNF} \alpha$ firstly was known as necrosis-inducer in tumor cells, later it was well known that TNF $\alpha$ is proinflammatory cytokine formed by epithelial cells, in addition to macrophages and monocytes in response to inflammatory or any injury causes ${ }^{(11,12,13)}$. It induces the action of cell adhesion molecules of tumor cells to be inducted through the vessels ${ }^{(14)}$. It was found that TGF- $\alpha$ protein was expressed in OSCC micovessels, endothelial cells ${ }^{(15)}$, TNF- $\alpha$ has more biological functions of cell apoptosis, cell proliferation, and differentiation ${ }^{(16)}$.

It was reported that there is a genetic proof that keratin 17 (K17) adjust TNF $\alpha$ function in hair cycling specific context, and a biochemical proof that TNF $\alpha$ signaling is enhanced in K17-null mouse skin tissue ${ }^{(17)}$. Where keratin gene expression is related to changes of keratinocytes, phenotype in both skin and oral epithelium ${ }^{(18,19)}$.

Keratins are one of the major epithelial cells filamentous proteins ${ }^{(20)}$, their gene family is large family of 54 functional genes ${ }^{(21)}$. Abnormal keratin expression is seen in cancer cells ${ }^{(22)}$. In OSCC, a comprehensive study showed overregulation of keratins 6,16 and 17 , with clear expression of $\mathrm{k} 17^{(23)}$. 
Moreover K 17 in normal oral epithelial tissue was defined as marker of basal cell ${ }^{(24)}$ and suprabasal hyperproliferation ${ }^{(25)}$, its expression in case of OSF was significantly increased in correlation with the severity of the disease within suprabasal layers of the epithelium ${ }^{(26)}$.

The aim of this work is to clarify the pathological role of these related proteins TNF- $\alpha$ and K 17 during the development of OSF in rat model.

\section{MATERIAL AND METHODS}

\section{Animals}

Fifty pathologically free female rats age is about 8 weeks and weighing ranging (180-200 grams) were bought from animal laboratory, Faculty of Medicine, Cairo University. They were caged ten animals' cage in a clean well ventilated animal house. They were provided food and water adlibitum and 24 hours altered light and dark cycle, in an air conditioned room $\left(22 \pm 2{ }^{\circ} \mathrm{C}\right)$ and $55 \pm$ $10 \%$ humidity. They were divided into five groups randomly .The groups were named according to time of euthanization ( 2 weeks, 4 weeks, 6 weeks, 8 weeks) groups in addition to the control group.

\section{Bleomycin treatment}

Bleomycin (Bleocip, Cipla LTD, India, each vial of 15 units) was dissolved in $0.01 \mathrm{M}$ sterile phosphate buffer saline (PBS). (100) $\mu 1$ concentration of bleomycin was injected by 26 gauge needle subcutaneously into the rat right buccal mucosae daily for 2 to 8 weeks (3).

\section{Euthanization}

The animals were euthanized at the end of 2 , 4, 6 and 8 weeks, respectively, the control group was euthanized at the end of the experiment. They were euthanized with an overdose of inhalation chloroform. Then the treated buccal mucosae of the right side from all animals were surgically excised.

\section{Histopathology and immunohistochemistry staining}

The dissected buccal mucosae were divided into two halves, one was fixed and embedded in paraffin blocks for H\&E and for TNF- $\alpha$ antibody immunohistochemistry staining, and the second half was stored for K 17 enzyme linked immunosorbent assay (ELISA) test.

\section{Immunohistochemical staining}

The paraffin embedded tissues were sectioned at $2.5 \mu \mathrm{m}$ thick and mounted on positive charged slides (Super Frost Plus-Menzel GmbH), then they were deparaffinized and dehydrated. Tissue sections $(2.5 \mu \mathrm{m})$ were also submitted to immunohistochemical assay. Antigenic recuperation was performed by heat in citrate $\mathrm{pH} 6.0$ solution. Slides were left to cool for 30 minutes at room temperature. After cooling, the slides were submitted to peroxidase blocking with $\mathrm{H}_{2} \mathrm{O}_{2} 3 \%$ solution diluted in PBS (phosphate buffered saline) for 30 minutes. After protein blocking (PBS) for 1 hour, the specimens were incubated overnight with Tumor Necrosis Factor alpha (TNF- $\alpha)\left(\right.$ Abcam $^{\circledR}$, Cambridge, UK) in 1:100 dilution. Then, the primary antibody Simple Stain Rat MAX PO (Multi) Universal Immuno-peroxidase Polymer (anti-mouse and -rabbit) (Histofine ${ }^{\circledR}$, Nicherei Biosciences Inc., Tokyo, Japan) was used for 60 minutes. Next, the sections were incubated in revelation system 5,5-diaminobenzidine tetrahydrochloride (DAB) $\left(\right.$ Dako $^{\circledR}$, Carpinteria, CA, USA) was used for 5 minutes and the counter coloration was Harris hematoxylin, for 30 seconds.

\section{ELISA}

The second half of tissue samples were stored at $-80^{\circ} \mathrm{C}$ for keratin 17 assay. Using Custom ELISA kit, catalog number LS-F18600, it is targets KRT17/ CK17 / Cytokeratin 17 in rat, LS-F18600 is a 96 (ELISA) for detection of Rat KRT17 / CK17 / Cytokeratin 17. It is based upon a custom assay principle.

\section{Statistical analysis}

Statistical analysis was then performed using a commercially available software program (SPSS 18; SPSS, Chicago, IL, USA). As data most of the data were parametric, independent $t$ test was used 
to compare epithelium and connective tissue. One way analysis of variance (ANOVA) test followed by Tukey's post hoc test was used for comparison between different observations within the same tissue. The level of significance was set at $\mathrm{P}<0.05$.

\section{RESULTS}

\section{Clinical results}

Clinical examination of the rat oral cavity was difficult due to their small size, it depended on visual observation without photographing.

\section{H\&E staining}

The buccal mucosae of the control group, at the end of the experiment, showed hyperplastic epithelium. The underlying lamina propria showed few inflammatory cells infiltration and no vascular changes Fig. (1A).

The test groups showed changes in both epithelial tissue and lamina propria of the buccal mucosae as follow: at $\mathbf{2}$ weeks, the epithelial tissue showed some broad and short rete ridges with hyperplastic, hyperatrophic changes, with minimal epithelial atrophy and elongated and dysplastic rete ridges in small areas, while the lamina propria showed obvious inflammatory cells infiltration, unclear muscle atrophy, no blood vessel changes with few fine collagen fibers formation, Fig. (2A), at 4 weeks the epithelial tissue showed focal broad and short rete ridges, atrophic epithelium and epithelial dysplasia was seen in more areas, while the lamina propria showed inflammatory cells infiltration, some muscle fibers were atrophic and blood vessel started to show closure with increased collagen fibers formation Fig. (3A), at 6 weeks the epithelial tissue showed elongated dyplastic rete ridges, with increased epithelial dysplasia and atrophic epithelial layers, on the other hand, lamina propria showed inflammatory cells infiltration, clear muscle atrophy and blood vessel closure with more collagen fibers formation. Fig. (4A), at 8 weeks (end of the experiment) the epithelial tissue showed more epithelial dysplasia with elongated dyplastic rete ridges and thin and atrophic epithelial layers, while the lamina propria showed, obvious muscle atrophy, blood vessel closure and collagen fibers band was expanded and few inflammatory cells infiltration were seen Fig. (5A).

\section{Immunohistochemical analysis TNF- $\alpha$}

At the end of the experiment, the buccal mucosae of the control group, showed low expression of $\mathrm{TNF} \alpha$ within basal and suprabasal layers, Fig.(1B) while the test groups showed gradual increase in expression of $\mathrm{TNF} \alpha$ within basal and suprabasal layers of epithelium from the second week up to $8^{\text {th }}$ week , While TNF $\alpha$ immunoexpression within connective tissue increased gradually from 2,4 and 6 weeks, then decreased at week 8 specially in hylanized subepithelial areas of lamina propria Fig. (2B-5B),respectively.

\section{ELISA}

For ELISA test K 17, showed gradual increase from the second up to $8^{\text {th }}$ weeks in comparison with its lowest level in the control group.

\section{STATISTICAL ANALYSIS}

\section{I-Regarding TNF- $\alpha$}

\section{1-Comparison within the same tissue (Effect of time)}

In the epithelium, the mean area percent gradually increased by time to reach its highest level at $8^{\text {th }}$-weeks. ANOVA test revealed that the difference was extremely significant $(\mathrm{P}<0.0001)$. Tukey's post hoc test revealed no significant difference between mean area percent of control, 2 and 4 weeks (Table 1, Fig.6).

In the connective tissue, the mean area percent gradually increased by time to reach its highest level at 6 weeks, then subsequently decreased at 8 weeks to reach $(7.91 \pm 3.04)$. ANOVA test revealed that the difference was highly significant $(\mathrm{P}=0.002)$. Tukey's post hoc test revealed that values at 2 and 8 weeks were not significant from mean area percent of control, 4 and 6 weeks (Table 1, Fig.6). 


\section{(H\&E)}

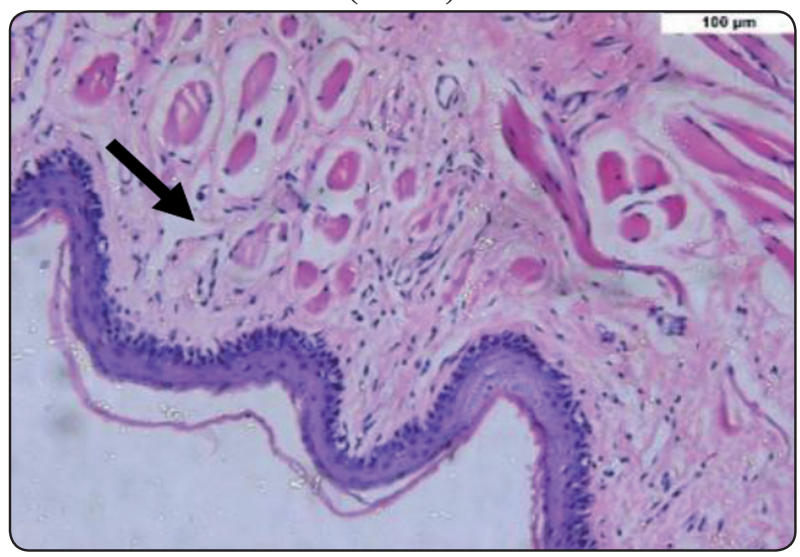

Fig (1A) A photomicrograph of control group showing hyperplastic epithelium, normal appearing blood Vessels (arrow), few inflammatory cells .(H\&E X 200).

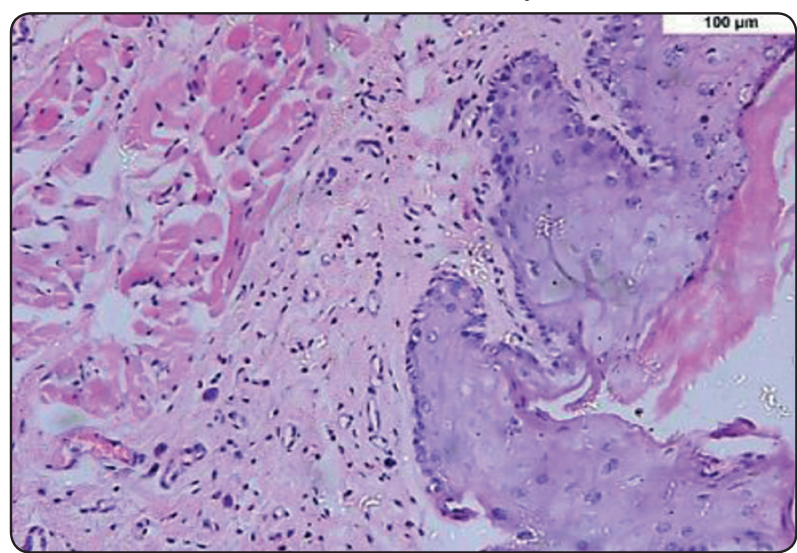

Fig (2A): A photomicrograph of test group (2ws) showing hyperkeratinization, elongated and dysplastic rete ridges, fine collagen formation, clear inflammatory cell infiltration and normal appearing blood vessels (H\&E X 200) .

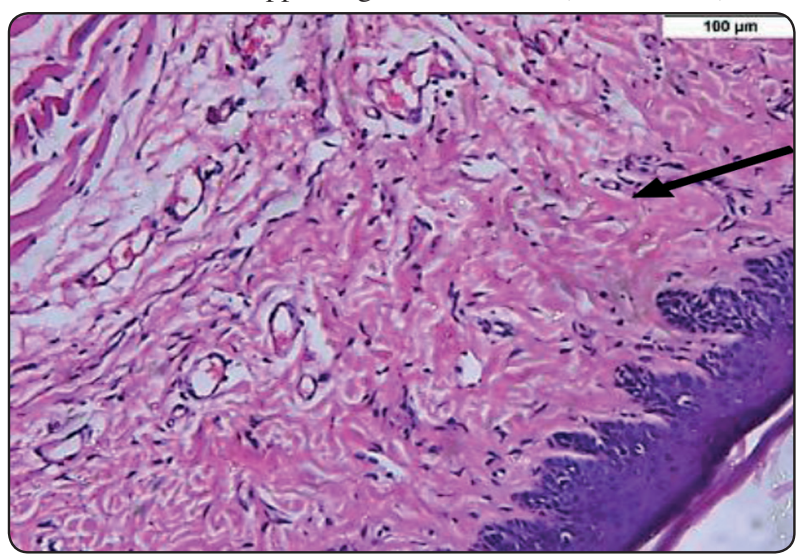

Fig (3A): A photomicrograph of test group (4ws) showing hyperkeratinization, elongated and dysplastic rete ridges, increased collagen fibers formation (arrow) inflammatory cell infiltration, little muscle atrophyand thickening of blood Vessels lining (H\&E x200).

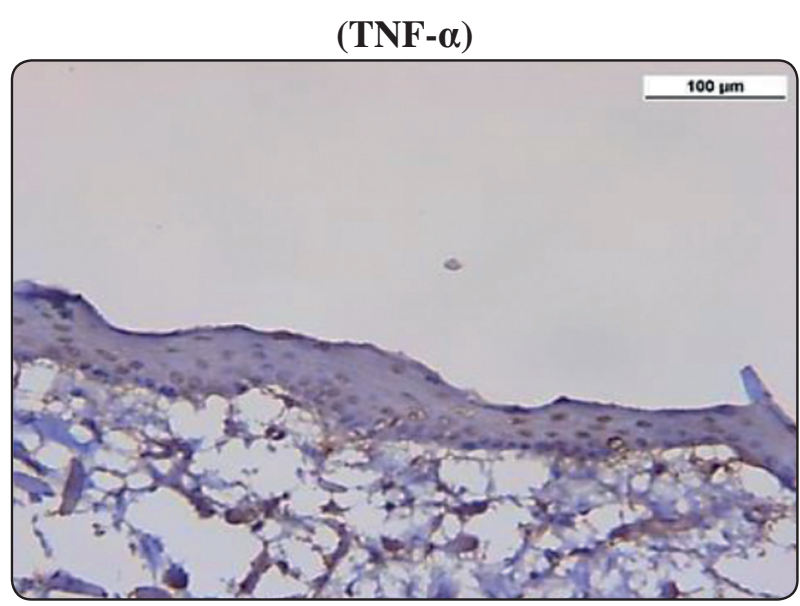

Fig (1B) A photomicrograph of of control group showing weak staining within basal and suprabasal epithelium layers and lamina propria (TNF- $\alpha$ x200).

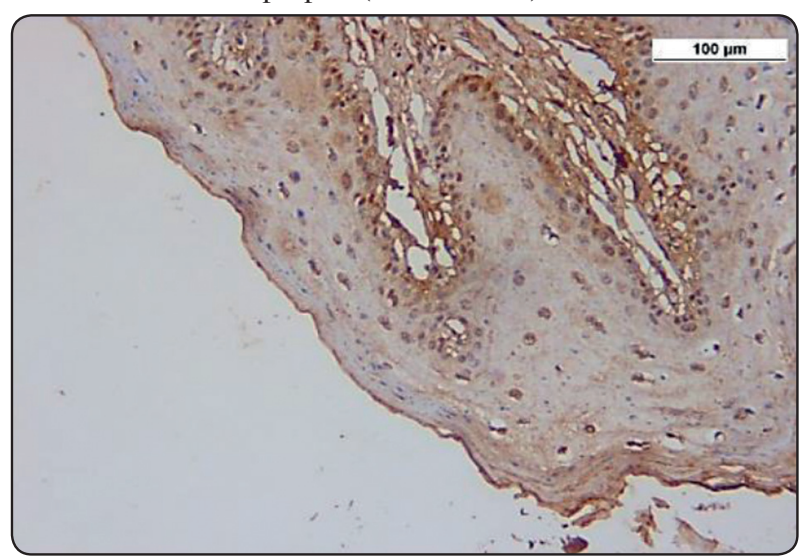

Fig (2B) A photomicrograph of test group (2ws) showing faint immunostaining within basal and suprabasal epithelium layers and lamina propria layers. (TNF- $\alpha$ x200).

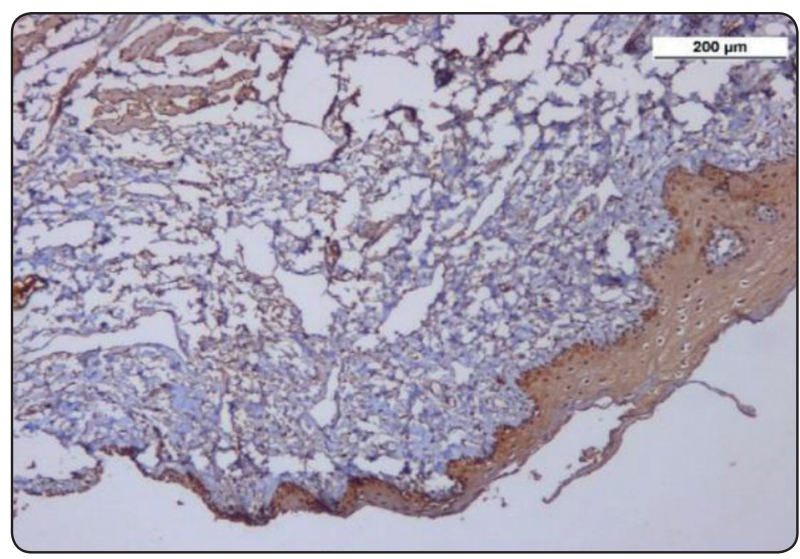

Fig (3B): A photomicrograph of test group (4ws) showing increased immunostaining of TNF- $\alpha$ within basal and suprabasal epithelium layers and lamina propria layers. (TNF- $\alpha$ x100). 
(H\&E)

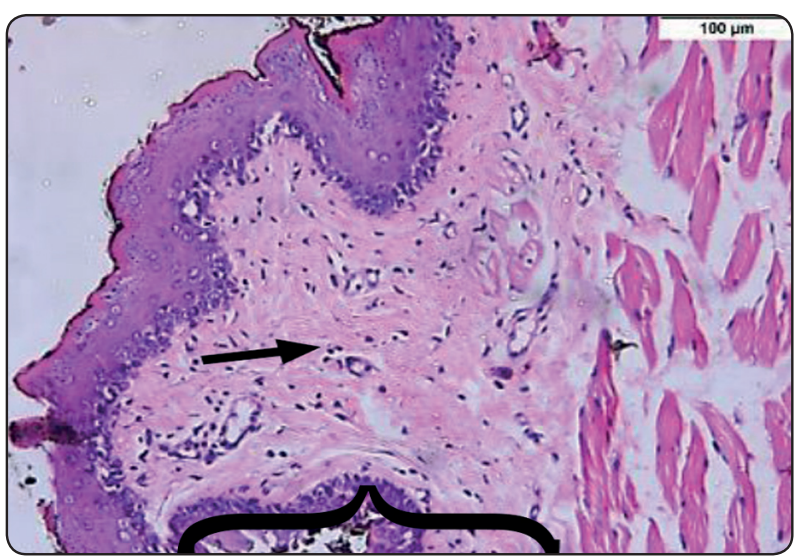

Fig (4A): A photomicrograph of test group (6ws) showing elongated and dyplastic rete ridges, collagen formation area (brace), inflammatory cells, atrophied muscle and closure of blood vessels (arrow) (H\&E x200).

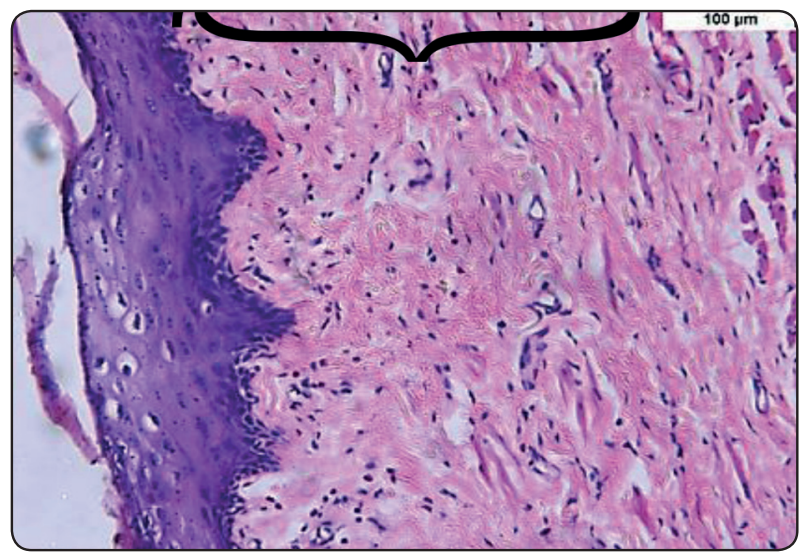

Fig (5A): A photomicrograph of test groups ( $8 \mathrm{ws}$ ) showing elongated dysplastic rete ridges, thickening of expanded collagen band (brace), more muscle atrophy and obvious congested blood vessels and fewinflammatory cells infiltration (8ws) (H\&E x200).

\section{2- Comparison between epithelium and connective tissue}

In Control, higher mean value was recorded in connective tissue, with no significant difference $(\mathrm{p}=0.357)$. At 2 weeks, higher mean value was recorded in connective tissue, with statistically significant difference $(\mathrm{p}=0.022)$. At 4 weeks, higher mean value was recorded in epithelium, with no significant difference $(p=0.504)$. At 6 weeks, higher mean value was recorded in epithelium, with statistically significant difference $(p=0.012)$.

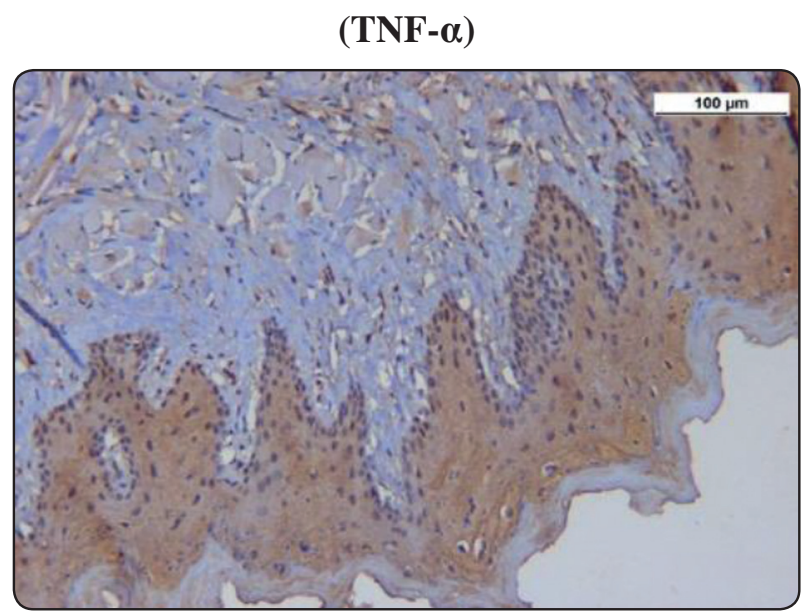

Fig (4B) : A photomicrograph of test group (6ws) showing more TNF- $\alpha$ immunostaining within basal and suprabasal epithelium layers and more staining of lamina propria layers. (TNF- $\alpha$ x200).

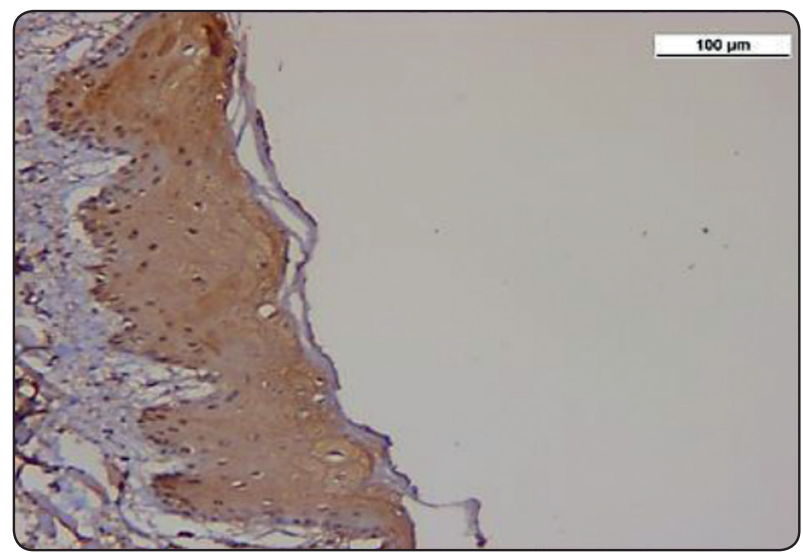

Fig (5B) : A photomicrograph of test group (8ws) is showing obvious strong immunostaining within basal and suprabasal epithelium layers and weak staining in lamina propria layers (TNF- $\alpha$ x200).

At 8 weeks, higher mean value was recorded in epithelium, with statistically significant difference $(\mathrm{p}=0.002)$ (Table 2, Fig.6)

III- Regarding Keratin-17, the lowest mean value was recorded in control. The mean value gradually increased after 2, 4, 6 and 8weeks. ANOVA test revealed that the difference was statistically significant $(\mathrm{p}<0.0001)$. Tukey's post hoc test revealed no significant difference between mean values recorded at 4 and 6 weeks (Table 3, Fig.7). 
TABLE (1) Comparison of values of area percent in different observations within the same tissue (ANOVA test).

\begin{tabular}{|c|c|c|c|c|c|c|c|c|}
\hline \multirow[b]{2}{*}{ Tissue } & \multirow[b]{2}{*}{ Groups } & \multirow[b]{2}{*}{ Mean } & \multirow[b]{2}{*}{ Std. Dev } & \multirow[b]{2}{*}{ Std. Error } & \multicolumn{2}{|c|}{ 95\% Confidence Interval for Mean } & \multirow[b]{2}{*}{ Min } & \multirow[b]{2}{*}{$\operatorname{Max}$} \\
\hline & & & & & Lower Bound & Upper Bound & & \\
\hline \multirow[t]{6}{*}{ Epithelium } & Control & $3.32^{\mathrm{c}}$ & 1.36 & .68 & 1.15 & 5.48 & 1.41 & 4.31 \\
\hline & 2 weeks & $4.64^{\mathrm{c}}$ & .74 & .37 & 3.47 & 5.81 & 3.79 & 5.42 \\
\hline & 4 weeks & $12.19^{\mathrm{c}}$ & 2.29 & 1.15 & 8.54 & 15.84 & 9.93 & 15.32 \\
\hline & 6 weeks & $26.30^{\mathrm{b}}$ & 5.93 & 2.96 & 16.87 & 35.73 & 21.71 & 34.70 \\
\hline & 8 weeks & $35.09^{\mathrm{a}}$ & 7.40 & 3.70 & 23.31 & 46.86 & 25.98 & 41.18 \\
\hline & \multicolumn{8}{|c|}{$\mathbf{P}<0.0001 *$} \\
\hline \multirow[t]{6}{*}{ Connective tissue } & Control & $4.29^{\mathrm{b}}$ & 1.40 & .70 & 2.05 & 6.53 & 2.79 & 5.59 \\
\hline & 2 weeks & $8.02^{\mathrm{a}, \mathrm{b}}$ & 1.72 & .86 & 5.28 & 10.77 & 6.32 & 10.29 \\
\hline & 4 weeks & $10.78^{\mathrm{a}}$ & 2.17 & 1.09 & 7.32 & 14.23 & 7.61 & 12.57 \\
\hline & 6 weeks & $10.95^{\mathrm{a}}$ & 1.21 & .60 & 9.02 & 12.87 & 10.24 & 12.75 \\
\hline & 8 weeks & $7.91^{\mathrm{a}, \mathrm{b}}$ & 3.04 & 1.52 & 3.08 & 12.74 & 5.54 & 12.26 \\
\hline & \multicolumn{8}{|c|}{$\mathrm{F}=7.22, \quad \mathrm{P}=0.002 *$} \\
\hline
\end{tabular}

Significance level $p<0.05$, *significant. Tukey's post hoc test: within the same comparison, means sharing the same superscript letter are not significantly different

TABLE (2) Comparison of values of area percent in different observations within the same tissue (Independent $\mathrm{t}$ test)

\begin{tabular}{|c|c|c|c|c|c|c|}
\hline \multirow{2}{*}{ Groups } & \multicolumn{2}{|c|}{ Epithelium } & \multicolumn{2}{c|}{ Connective tissue } & \multirow{2}{*}{$\mathrm{t}$} \\
\cline { 2 - 6 } & Mean & Std. Dev & Mean & Std. Dev & & P \\
\hline Control & 3.32 & 1.36 & 4.29 & 1.40 & 0.997 & $0.357 \mathrm{NS}$ \\
\hline 2 weeks & 4.64 & .74 & 8.02 & 1.72 & 3.61 & $0.022^{*}$ \\
\hline 4 weeks & 12.19 & 2.29 & 10.78 & 2.17 & 0.896 & $0.504 \mathrm{NS}$ \\
\hline 6 weeks & 26.30 & 5.93 & 10.95 & 1.21 & 5.08 & $0.012^{*}$ \\
\hline 8 weeks & 35.09 & 7.40 & 7.91 & 3.04 & 6.8 & $0.002^{*}$ \\
\hline
\end{tabular}

\section{Significance level $p<0.05$, *significant,$\quad$ NS=non-significant}

TABLE (3) values of Keratin 17 at different observation times

\begin{tabular}{|c|c|c|c|c|c|c|c|c|}
\hline & & control & 2 weeks & 4 weeks & 6 weeks & 8 weeks & $\mathrm{F}$ & $\mathrm{P}$ \\
\hline \multirow{4}{*}{$\begin{array}{c}\text { Keratin } 17 \\
(\mathrm{ng} / \mathrm{ml})\end{array}$} & Mean & $0.32^{\mathrm{d}}$ & $0.95^{\mathrm{c}}$ & $1.51^{\mathrm{b}}$ & $1.94^{\mathrm{b}}$ & $3.13^{\mathrm{a}}$ & \multirow{4}{*}{15.9} & \multirow{4}{*}{$<0.0001^{*}$} \\
\hline & Std Dev & 0.10 & 0.31 & 0.52 & 0.60 & 1.02 & & \\
\hline & Max & 0.51 & 1.40 & 1.90 & 2.50 & 5.10 & & \\
\hline & Min & 0.22 & 0.56 & 0.92 & 1.30 & 1.60 & & \\
\hline
\end{tabular}

Significance level $p<0.05$, *significant 


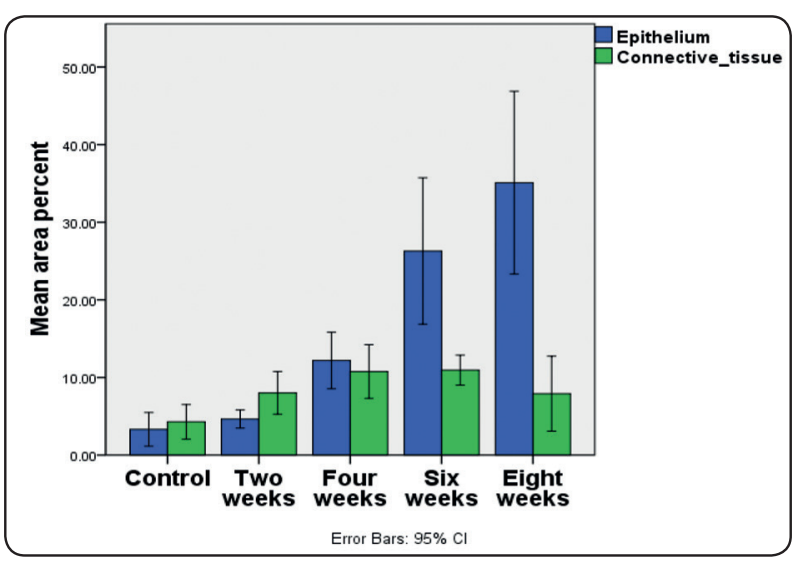

Fig. (6) Bar chart showing mean values of area percent in different observations in epithelium and connective tissue.

\section{DISCUSSION}

This study was designed to explain the pathological role of the related proteins TNF- $\alpha$ and $\mathrm{K} 17$ in oral submucous fibrosis in rat model induced by bleomycin. As it was proved before by Zhang S.et al.(2016), that OSF of human are similar to OSF of rat model induced by bleomycin in both clinical and pathological features ${ }^{(3)}$.

It was estimated that about seven to twelve percent of OSF cases develop different grades of oral epithelial dysplasia with liability to transform into oral squamous cell carcinoma ${ }^{(27)}$. It was reported by Gupta et al.,(2008) and Yoithapprabhunath et al., (2013) that approximately similar percent (7 to 13) of OSF transformed into oral squamous cell carcinoma ${ }^{(28,29)}$.

The clinical observation of this study was difficult because of the narrow mouth opening. This might be due to the fibrosis which was observed in histological sections as it gradually increased from the second week to $8^{\text {th }}$ weeks. In agreement with this observation, Haider, et al.(2000) proposed that the difficulty of mouth-opening could be used as an indicator of OSF severity due to fibrous bands formed mainly at the mouth distal part (in mild cases) and progressed in anterior areas with increased severity of the OSF in mice model ${ }^{(30)}$.

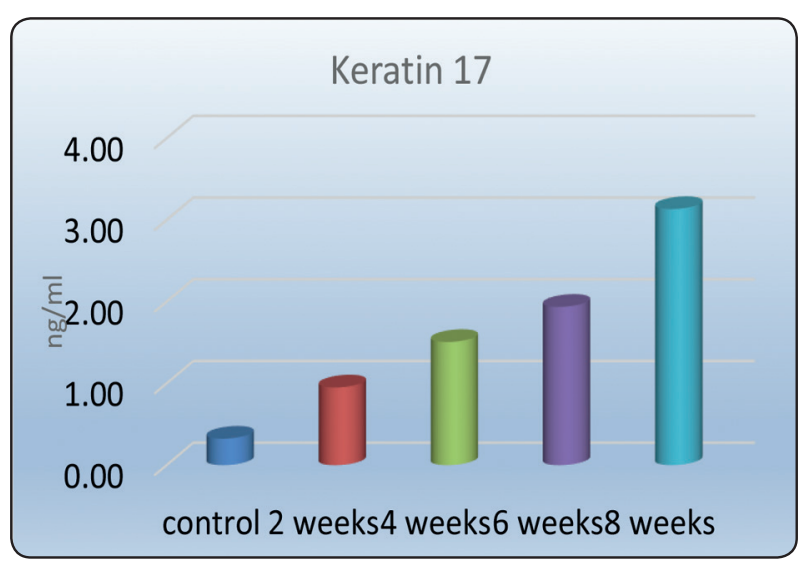

Fig. (7) Column chart showing mean values of Keratin $17(\mathrm{ng} / \mathrm{nl})$

In the present study, the epithelium of the control group showed hyperplastic epithelium, while the lamina propria of the control group showed few inflammatory cells infiltration, normal appearing of muscle fibers, absence of collagen fibers formation and no vascular changes, the same observations were reported by Zhang S. et al., (2016) who referred these changes to the inflammatory effect of injecting sterile phosphate buffer saline (PBS) ${ }^{(3)}$.

Results of the test groups revealed regression of epithelial changes from hyperplastic and hyperatrophic epithelium to epithelial atrophy and focal dysplastic changes. These changes increased with severity of OSF involving large areas. In accordance with researchers'observation, where the thickness of epithelium differs widely with severity of $\mathrm{OSF}^{(31)}$, atrophy, hyperplasia and dysplasia where the epithelial dysplastic changes in OSF increased with the severity of $\operatorname{OSF}^{(3,7)}$.

The histological changes in the lamina propria showed obvious increase of inflammatory infiltration at 2, 4, 6 weeks, which reduced at 8 weeks with increased severity of OSF (end of experiment). Moreover increase of fibrosis, decreased vasculature and obliteration of the local vasculature. It was progressed that this histological changes could provide long time for inflammatory cytokines to be formed to allow the malignant transformation 
of $\operatorname{OSF}^{(31)}$. This findings were reported by other researches ${ }^{(32,33,34)}$.

Ray et al.(2016), concluded that OSF cases can be transformed into OSCC, sharing common protein markers involved in pathogenesis of both OSF and OSCC ${ }^{(7)}$.One of this markers is TNF- $\alpha$, where its immunoexpression, within the epithelium layers had increased gradually from 2,4 ,6 weeks and 8 weeks, while lamina propria showed gradual increase from 2,4, 6 and decreased in 8 weeks, especially in hylanized areas. In parallel with this finding within epithelium, an increase of TNF- $\alpha$ level saliva from normal control to premalignant to its maximum in OSCC cases ${ }^{(35)}$. Moreover, there was an increase of TNF- $\alpha$ serum level of OSCC patients $^{(36,37,38)}$, that was closely related to poor prognosis of $\mathrm{OSCC}^{(39)}$. It was proposed that TNF$\alpha$ produced by keratinocytes (during pathological conditions) ${ }^{(40,41)}$, TNF- a has different biological functions as allowing their mobility to migrate, through regulation of cytoskeleton genes, as well as affecting cell cycle and apoptosis of keratinocytes ${ }^{(40)}$.

The gradual increase of the TNF $\alpha$ immunoexpression in lamina propria from 2 up to 6 weeks. It could be due to its role in pathological collagen synthesis in the lamina propria ${ }^{(40)}$. In the present study the increase and decrease of TNF $\alpha$ as an proinflammatory cytokine produced by the inflammatory cells ${ }^{(11,12,13)}$, was parallel to the increase and decrease of the inflammatory cells infiltration.

In this work visualization of TNF- $\alpha$ using immunoexpression and K17 using ELISA on tissue level of OSF is considered as new interpretation of TNF- $\alpha$ and K 17 by those techniques. K17 and TNF- $\alpha$ are related proteins. K17 has a role in protecting keratinocytes during inflammation, apoptosis debilitation through TNF- $\alpha$, that allow the survival of keratinocytes during stress period ${ }^{(17,40)}$. Also a pervious study by Khanom, et al., proved that $\mathrm{K} 17$ has a tumorigenic effect in OSCC through facilitating tumor cell growth ${ }^{(42)}$.
In present study the $\mathrm{K} 17$ expression, using ELISA, technique had gradually increased with the increased severity of OSF from the second week up to $8^{\text {th }}$ week. Our results was in accordance with Lalli et al., (2008) who showed that K 17 expression in suprabasal layers were increased in correlation with severity of OSF ${ }^{(26)}$.

The biological roles of epithelial - mesenchymal interaction allow differentiation, proliferation, migration and invasion of keratinocyte $(43,44)$. Depending on the immunity principles ,two ways action of TNF- $\alpha$ and K 17, is clear ,to explain how active keratinocytes could initiate inflammation at injury site and vice versa, where TNF- $\alpha$ release from inflammatory cells, at the site of injury or stress to activate the immunity which later induce the production of IL- $1^{(45)}$. Freedberg, et al., (2001) reported that IL-1 also is release from keratinocytes to activate lymphocytes and fibroblasts at the site of injury and also activate keratinocytes themselves for hyperproliferation and migration. The activated keratinocytes induce release of TNF- $\alpha$ which keep the keratinocytes active until the interferon- $\alpha$ (IFN- $\alpha$ ) released from lymphocytes to activate keratinocytes, allowing the expression of K 17 by keratinocytes $^{(40)}$.

The changes in keratin expression have been reported in both vivo and in vitro models depending on the mesenchymal changes ${ }^{(46,47)}$. Furthermore K 17 is expressed in many healthy tissue cells like basal layers of transitional and pseudostratifed epithelium of the respiratory and urinary tracts, myoepithelial cells, during developmental stages of stratifed epithelium where it promote the contractile properties ${ }^{(48)}$.

Finally, this study proved that the need of contractile function by $\mathrm{K} 17$ is increased with the increase of the severity of OSF to protect keratinocytes from apoptosis, which is one of the main biological functions of TNF- $\alpha$ at the injury site. 


\section{CONCLUSION}

Both protein molecules TNF- $\alpha$ and K17 appear to be related in case of oral submucous fibrosis .As K17 and TNF- $\alpha$ are interdependent regulators, they could be used as diagnostic makers and a prognostic mirror of oral submucous fibrosis cases. TNF- $\alpha$ inhibitory drugs can be targeted in new therapeutic agents to improve the prognosis of oral submucous fibrosis.

\section{REFERENCES}

1. Chua F, Gauldie J, Laurent GJ. Pulmonary fibrosis: Searching for model answers. Am J Respir Cell Mol Biol. 2005;33(1):9-13.

2. Crouch E. Pathobiology of pulmonary fibrosis. Am J Physiol. 1990 Oct;259(4 Pt 1):L159-84.

3. Zhang S, Gong Z, Xiong W, Wang X, Min Q, Luo C, Ling TY. A Rat Model of Oral Submucous Fibrosis Induced by Bleomycin. Oral Surg Oral Med Oral Pathol Oral Radiol. 2016 Aug 1;122(2):216-23.

4. International Agency for Research on Cancer. IIARC Monographs on the Evaluation of Carcinogenic Risks to Humans - Betel-quid and Areca-nut Chewing and Some Areca-nut-derived Nitrosamines . Vol. 85, World Health Organization. 2004.

5. Chiba I. Prevention of Betel Quid Chewers' Oral Cancer in the Asian-Pacific Area. Asian Pac J Cancer Prev. 2001;2(4):263-9.

6. Passi D, Bhanot P, Kacker D, Chahal D, Atri M, Panwar Y. Oral submucous fibrosis: Newer proposed classification with critical updates in pathogenesis and management strategies. Natl J Maxillofac Surg . 2017;8(2):89.

7. Ray JG, Ranganathan K, Chattopadhyay A. Malignant transformation of oral submucous fibrosis: overview of histopathological aspects. Oral Surg Oral Med Oral Pathol Oral Radiol. 2016 Aug;122(2):200-9.

8. Arakeri G, Brennan PA. Oral submucous fibrosis: an overview of the aetiology, pathogenesis, classification, and principles of management. Br J Oral Maxillofac Surg. 2013 Oct ;51(7):587-93.

9. Tilakaratne WM, Klinikowski MF, Saku T, Peters TJ, Warnakulasuriya S. Oral submucous fibrosis: review on aetiology and pathogenesis. Oral Oncol. $2006 \mathrm{Jul}$; 42(6):561-8.
10. Chang MC, Lin LD, Wu HL, Ho YS, Hsien HC, Wang TM, Jeng PY, Cheng RH, Hahn LJ, Jeng JH. Areca nut-induced buccal mucosa fibroblast contraction and its signaling: a potential role in oral submucous fibrosis--a precancer condition. Carcinogenesis . 2013 May 1 ;34(5):1096-104.

11. Köck A, Schwarz T, Kirnbauer R, Urbanski A, Perry P, Ansel JC, Luger TA.. Human keratinocytes are a source for tumor necrosis factor alpha: evidence for synthesis and release upon stimulation with endotoxin or ultraviolet light. J Exp Med. 1990 Dec 1 ;172(6):1609-14.

12. Nickoloff BJ, Karabin GD, Barker JN, Griffiths CE, Sarma V, Mitra RS,Elder JT, Kunkel SL, Dixit VM . Cellular localization of interleukin-8 and its inducer, tumor necrosis factor-alpha in psoriasis. Am J Pathol. 1991 Jan;138(1):129-40.

13. Kolde G, Schulze-Osthoff K, Meyer H, Knop J. Immunohistological and immunoelectron microscopic identification of TNF alpha in normal human and murine epidermis. Arch Dermatol Res. 1992;284(3):154-8.

14. Wenzel CT, Scher RL, Richtsmeier W. Adhesion of Head and Neck Squamous Cell Carcinoma to Endothelial Cells: The Missing Links. Arch Otolaryngol - Head Neck Surg . 1995 Nov 1 ;121(11):1279-86.

15. Nakano Y, Kobayashi W, Sugai S, Kimura H, Yagihashi S. Expression of tumor necrosis factor-alpha and interleukin-6 in oral squamous cell carcinoma. Jpn J Cancer Res. 1999 Aug ;90(8):858-66.

16. Szlosarek P, Charles KA, Balkwill FR. Tumour necrosis factor- $\alpha$ as a tumour promoter. Eur J Cancer. 2006 Apr;42(6):745-50.

17. Tong X, Coulombe PA. Keratin 17 modulates hair follicle cycling in a TNF -dependent fashion. Genes Dev. 2006 May 15;20(10):1353-64.

18. Waseem A, Dogan B, Tidman N, Alam Y, Purkis P, Jackson S, Lalli A, Machesney M, Leigh IM.. Keratin 15 expression in stratified epithelia: downregulation in activated keratinocytes. J Invest Dermatol . 1999 Mar;112(3):362-9.

19. Bloor BK, Tidman N, Leigh IM, Odell E, Dogan B, Wollina U, Ghali L, Waseem A._Expression of keratin K2e in cutaneous and oral lesions: association with keratinocyte activation, proliferation, and keratinization. Am J Pathol. 2003 Mar;162(3):963-75.

20. Fuchs E. Keratins and the Skin. Annu Rev Cell Dev Biol. 1995 Nov;11(1):123-54. 
21. Quinlan RA, Schiller DL, Hatzfeld M, Achtstätter T, Moll R, Jorcano JL, Magin TM, Franke WW. Patterns of expression and organization of cytokeratin intermediate filaments. Ann N Y Acad Sci . 1985;455:282-306.

22. Moll R, Divo M, Langbein L. The human keratins: biology and pathology. Histochem Cell Biol . 2008 Jun 7; 129(6):705-33.

23. Sakamoto K, Aragaki T, Morita K, Kawachi H, Kayamori $\mathrm{K}$, Nakanishi S, et al. Down-regulation of keratin 4 and keratin 13 expression in oral squamous cell carcinoma and epithelial dysplasia: a clue for histopathogenesis. Histopathology. 2011 Mar 1;58(4):531-42.

24. Ranganathan K, Kavitha R, Sawant SS, Vaidya MM. Cytokeratin expression in oral submucous fibrosis--an immunohistochemical study. J Oral Pathol Med . 2006 Jan; 35(1):25-32.

25. van der Velden LA, Manni JJ, Ramaekers FC, Kuijpers W. Expression of intermediate filament proteins in benign lesions of the oral mucosa. Eur Arch Otorhinolaryngol. 1999 ;256(10):514-9.

26. Lalli A, Tilakaratne WM, Ariyawardana A, Fitchett C, Leigh IM, Hagi-Pavli E, Cruchley AT, Parkinson EK, Teh MT, Fortune F, Waseem A. An altered keratinocyte phenotype in oral submucous fibrosis: correlation of keratin K17 expression with disease severity. J Oral Pathol Med. 2008 Apr 19;37(4):211-20.

27. Bouquot JE, Speight PM, Farthing PM. Epithelial dysplasia of the oral mucosa-Diagnostic problems and prognostic features. Curr Diagnostic Pathol. 2006 Feb 1;12(1):11-21.

28. Gupta MK, Mhaske S, Ragavendra R. Oral submucous fibrosis -Current Concepts in Etiopathogenesis. People's J Sci Res.2008 July;1(1):39-44.

29. Yoithapprabhunath TR, Maheswaran T, Dineshshankar J, Anusushanth A, Sindhuja P, Sitra G. Pathogenesis and therapeutic intervention of oral submucous fibrosis. J Pharm Bioallied Sci. 2013 Jun ;5(Suppl 1):S85-8.

30. Haider SM, Merchant AT, Fikree FF, Rahbar MH. Clinical and functional staging of oral submucous fibrosis. Br J Oral Maxillofac Surg . 2000 Feb;38(1):12-5.

31. Garg N, Mehrotra R R. Morphometric analysis of epithelial thickness and blood vessels in different grades of oral submucous fibrosis. Malays J Pathol. 2014 Dec;36(3):189-93.

32. Tekade SA, Chaudhary MS, Tekade SS, Sarode SC, Wanjari SP, Gadbail AR, et al. Early Stage Oral Submucous
Fibrosis is Characterized by Increased Vascularity as Opposed to Advanced Stages. J Clin Diagnostic Res. 2017 May ;11(5):ZC92-ZC96.

33. Murgod V V, Kale AD, Angadi P V, Hallikerimath S. Morphometric analysis of the mucosal vasculature in oral submucous fibrosis and its comparison with oral squamous cell carcinoma. J Oral Sci. 2014 Jun ;56(2):173-8.

34. Choudhari SS, Kulkarni DG, Patankar S, Kheur SM, Sarode SC, Sarode GS, Patil S. Angiogenesis and Fibrogenesis in Oral Submucous Fibrosis: A Viewpoint. J Contemp Dent Pract. 2018 Feb 1;19(2):242-5.

35. Krishnan R, Thayalan DK, Padmanaban R, Ramadas R, Annasamy RK, Anandan N. Association of serum and salivary tumor necrosis factor- $\alpha$ with histological grading in oral cancer and its role in differentiating premalignant and malignant oral disease. Asian Pac J Cancer Prev. 2014;15(17):7141-8.

36. Gallo O, Pinto S, Boccuzzi S, Dilaghi M, Gallina E, Attanasio M, Gori AM, Martini F, Abbate R.. Monocyte Tumor Necrosis Factor Production in Head and Neck Squamous Cell Carcinoma. Laryngoscope . 1992 Apr;102(4):447-50.

37. Gallo O, Gori AM, Attanasio M, Martini F, Giusti B, Boddi M, Gallina E, Fini O, Abbate R. Interleukin-1 beta and interleukin- 6 release by peripheral blood monocytes in head and neck cancer. Br J Cancer . 1993 Sep;68(3):465-8.

38. Yamamoto T, Yoneda K, Ueta E, Osaki T. Serum cytokines, interleukin-2 receptor, and soluble intercellular adhesion molecule-1 in oral disorders. Oral Surg Oral Med Oral Pathol. 1994 Dec;78(6):727-35.

39. Yoneda K, Yamamoto T, Ueta E, Nakao K, Osaki T. Influence of aging and chemoradiotherapy on leucocyte function in oral cancer patients. Eur J Cancer B Oral Oncol. 1995 Mar ;31B(2):144-50.

40. Freedberg IM, Tomic-Canic M, Komine M, Blumenberg M, Ronald Perelman TO. Keratins and the Keratinocyte Activation Cycle . 2001;116(5):633-40.

41. Welss T, Basketter DA, Schröder KR. In vitro skin irritation: facts and future. State of the art review of mechanisms and models. Toxicol In Vitro. 2004 Jun;18(3):231-43.

42. Khanom R, Nguyen CTK, Kayamori K, Zhao X, Morita K, Miki Y, , Katsube K, Yamaguchi A, Sakamoto K. Keratin 17 Is Induced in Oral Cancer and Facilitates Tumor Growth. PLoS One. 2016 Aug 11;11(8):e0161163. 
43. Mackenzie IC. The role of epithelial-mesenchymal interactions in epithelial migration and differentiation. $\mathrm{J}$ Periodontal Res. 1984 Nov;19(6):656-60.

44. Mueller MM, Fusenig NE. Tumor-stroma interactions directing phenotype and progression of epithelial skin tumor cells. Differentiation. 2002 Dec;70(9-10):486-97.

45. Barker JN, Mitra RS, Griffiths CE, Dixit VM, Nickoloff BJ. Keratinocytes as initiators of inflammation. The Lancet. 1991 Jan 26 ;337(8735):211-4.

46. Mackenzie IC, Hill MW. Maintenance of regionally specific patterns of cell proliferation and differentiation in transplanted skin and oral mucosa. Cell Tissue Res. 1981;219(3):597-607.

47. Chinnathambi S, Tomanek-Chalkley A, Ludwig N, King E, DeWaard R, Johnson G, Wertz PW, Bickenbach JR Recapitulation of oral mucosal tissues in long-term organotypic culture. Anat Rec A Discov Mol Cell Evol Biol. 2003 Feb;270(2):162-74.

48. Troyanovsky SM, Leube RE, Franke WW. Characterization of the human gene encoding cytokeratin 17 and its expression pattern. Eur J Cell Biol. 1992 Oct;59(1): 127-37. 